\title{
TWO NEW TIGER BEETLES FROM NEW GUINEA ${ }^{1}$
}

By P. J. Darlington, Jr.

Museum of Comparative Zoölogy, Cambridge, Mass.

The following two new species of the well-studied family Cicindelidae are of unusual interest. One is the second known species of Caledonomorpha, the only genus of the family confined to New Guinea. The other constitutes the first record for New Guinea of the widely distributed genus Prothyma.

Caledonomorpha milneana n. sp. (Fig. 1)

Similar in generic characteristics, and nearly similar in form and general appearance, to Caledonomorpha jordani W. Horn (1897, pp. 270-271; 1910, p. 179, t. 11, f. 12), but slightly smaller and less elongate. Color of body green; but labrum testaceous basally; top of head (except labrum) and pronotum (except at sides) bluish purple; elytra brown with bluish or purplish reflections and green punctation, and each elytron with 3 small marginal or submarginal white spots, one humeral, one before middle, one ante-apical; abdomen piceous except green at sides anteriorly, testaceous apically. Surface of body including elytra with distinct, fine, isodiametric or slightly transverse, reticulate microsculpture. Mandibles piceous, except testaceous externally in basal half; palpi testaceous, each with apical segment entirely or partly piceous; antennæ piceous; legs piceous externally (with green reflections on basal half of femora), testaceous internally. Head: with mandibles elongate, each with 4 long teeth about as in jordani; mentum tooth long and acute; labrum transverse, not quite so short as in jordani, irregularly truncate, with one seta each side and 2 near middle; eyes prominent; antennæ very elongate; palpi long, slender. Prothorax subquadrate, longer than wide, transversely impressed and slightly constricted near base and apex, with median longitudinal line less impressed;

1 Published with a grant from the Museum of Comparative Zoölogy at Harvard College. 
disk slightly, transversely wrinkled, impunctate. Elytra relatively a little shorter than in jordani; each with outer apical angle spined, sutural angle not distinctly toothed, humeral prominence present but less developed and less acute than in jordani; surface moderately punctate, the punctures usually separated from each other by more than their own diameters. Male genitalia as figured.

Length 10-11; width between 3 and $3 \frac{1}{2} \mathrm{~mm}$.

Holotype $\delta$ and one $\delta$ paratype both from north side of Milne Bay, eastern tip of New Guinea, December 1943, taken by myself. Types in the Museum of Comparative Zoölogy: Type No. 27734.

This new species is slightly smaller and less elongate than Caledonomorpha jordani W. Horn, differs in ground color of the upper surface, lacks a distinct tooth at the apical sutural angle of the elytron, has less prominent and less acute humeral prominences, and differs slightly in other ways.

Caledonomorpha is the only genus of tiger beetles peculiar to New Guinea. C. jordani, the only previously known species, is apparently confined to eastern New Guinea and adjacent small islands. It was described from Fergusson (Island) and the Astrolabe Mts., and in the M.C.Z. we have a series of 8 specimens from Mt. Lamington and Dobodura. It is rather surprising to find a second eastern New Guinea species at Milne Bay. In case Horn's original series may have been mixed, I here designate the form figured in Genera Insectorum (W. Horn 1910, t. 11, f. 12) as typical jordani. Possibly additional species remain to be discovered in western New Guinea.

I collected $C$. jordani, in northern foothills of the Owen Stanley Range near Dobodura, on stones and shrubs along small, very rapid brooks in heavy forest. Probably C. milneana lives in a similar habitat, although I do not remember the circumstances under which the types were collected.

Prothyma papua n. sp. (Fig. 2)

A rather small Prothyma s. s. Brown-bronze above, 
purplish blue below ; elytra each with a narrow, irregular, yellowish white lateral vitta from behind humerus to apex; lateral (not apical) margin purplish blue, the color extending inward to form distinct marginal spots about $\frac{1}{3}$ from base and just behind middle, and less distinct spots behind humerus and near apical $\frac{1}{4}$ th; labrum bronze; mandibles and antennæ brown, latter paler near base; palpi irregularly brownish testaceous with apical
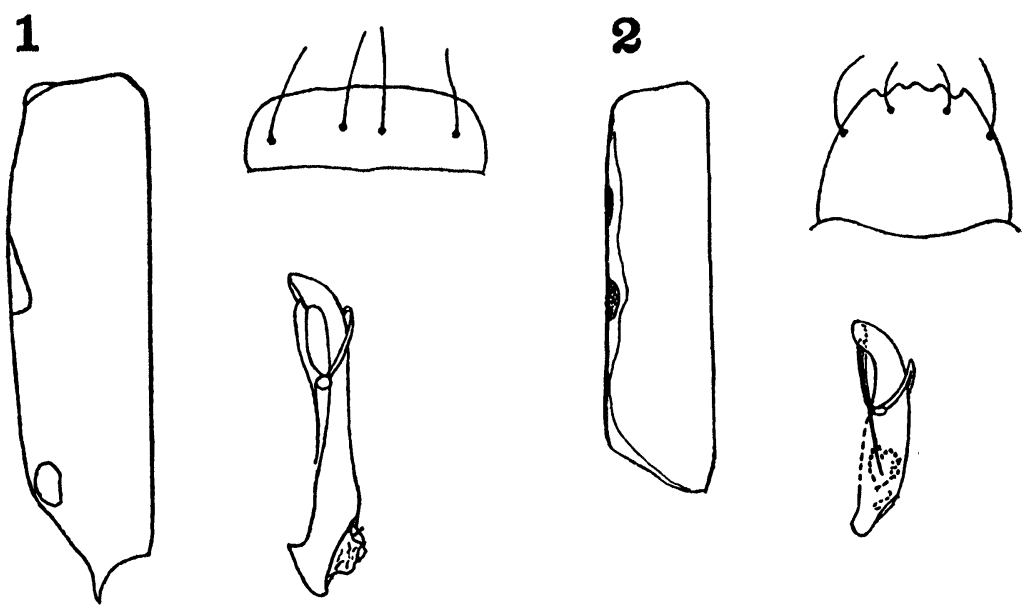

Fig. 1. Caledonomorpha milneana n. sp. (holotype). Camera-lucida outlines of left elytron (from perpendicular to suture), labrum, and male genitalia (from left, with left paramere).

Fig. 2. Prothyma papua n. sp. (holotype).

segments darker; legs irregularly brownish testaceous, paler internally, with femora vaguely spotted or banded with darker before apex; posterior tibiæ paler toward apex, but actual apices dark; posterior tarsi with 2 basal segments pale, 3 outer ones darker. Head: with labrum long, 5-dentate, 4-setose, with deep, almost isodiametric, reticulate microsculpture; clypeus without setæ; eyes very prominent; antennæ long (in genus), first segment of each with a single seta in front near apex; upper surface of head (except labrum) rugose, the rugosity becoming longitudinal between the eyes and forming about 32 parallel, somewhat anastomosing striæ; mentum tooth 
moderate, triangular; palpi slender (in genus). Prothorax small, quadrate, just wider than long (by measurement) ; pronotum with usual anterior and posterior transverse impressions; median longitudinal impression vague; surface rugose. Elytra obliquely sinuate-truncate at apex (more widely than usual); each with a small tooth at sutural angle; surface with microsculpture like labrum, and also moderately punctate, most of the punctures being rather small and separated from each other by much more than their own diameters; a few larger punctures, some bearing small hairs, scattered in basal $\frac{1}{3}$ of disk and widely spaced in one line on each elytron parallel to suture to within $\frac{1}{4}$ of apex. Lower surface of body not distinctly punctate and not pubescent except for setæ on all coxæ and pairs of setæ on 4th and 5th segments of abdomen; 6th ventral ( $\left.\delta^{\top}\right)$ deeply emarginate, without hairs (some hairs present on apparent 7 th segment); thighs without hooked hairs. Inner wings fully developed. Male with 3 basal segments of front tarsus slightly dilated, white, and pubescent below (outer segments slender, dark); male genitalia as figure.

Length 8; width c. $2 \frac{1}{2} \mathrm{~mm}$.

Holotype $\sigma^{\lambda}$ and one $\sigma^{\lambda}$ paratype, both from north side of Milne Bay, eastern tip of New Guinea, December 1943, taken by myself; ecological habitat not recorded. Types in Museum of Comparative Zoölogy : Type No. 27735.

To understand the relationships and geographical significance of this new species, one must understand first the previously known distribution of Prothyma. The genus in the strict sense includes some 50 species, of which a few are in Africa, many in Madagascar, 2 on Mauritius and Reunion, many in the Oriental Region east to Java and the Philippines, one in temperate China (W. Horn, 1935, p. 24), and one in southern Mexico in the edge of the American tropics. Until now, no Prothyma in the strict sense has been known east of Wallace's Line, but endemic subgenera, each with one or two species, are localized in Celebes, northwestern Australia (W. Horn, 1936, p. 22), New Caledonia, and Samoa (W. Horn, 1934, p. 144). These subgenera are marked either 
by a short labrum, or a bidentate labrum, or by reduction of width of head in relation to prothorax, characters that are not even suggested in the new New Guinea species. The latter is therefore not only the first Prothyma of any sort found in New Guinea, but it extends the known range of Prothyma s. s. into the Australian Region. It appears to be a very distinct species. It differs from most Oriental Prothyma (e.g., from quadripunctata F. and heteromalla Macl. of Java) in elytral color pattern, which in most Oriental species consists of white spots on a dark or metallic background, but which in papua consists of an incomplete pale submarginal and apical vitta partly interrupted by incursions of the narrow marginal metallic color. The elytra are wider near the apex in papua than in any other Prothyma of which I have seen specimens or figures.

\footnotetext{
Horn, W.

BIBLIOGRAPHY

1897. Ann. Mus. Civ. Stor. Nat. Genova, Vol. 37.

1910. Wytsman's Genera Insectorum, Fase. 82B.

1934. Natuurhistorisch Maanblad (Maastricht), Vol. 23.

1935. Arkiv för Zoologi, Vol. $27 \mathrm{~A}$, No. 4.

1936. Entomologische Blätter, Vol. 32.
} 

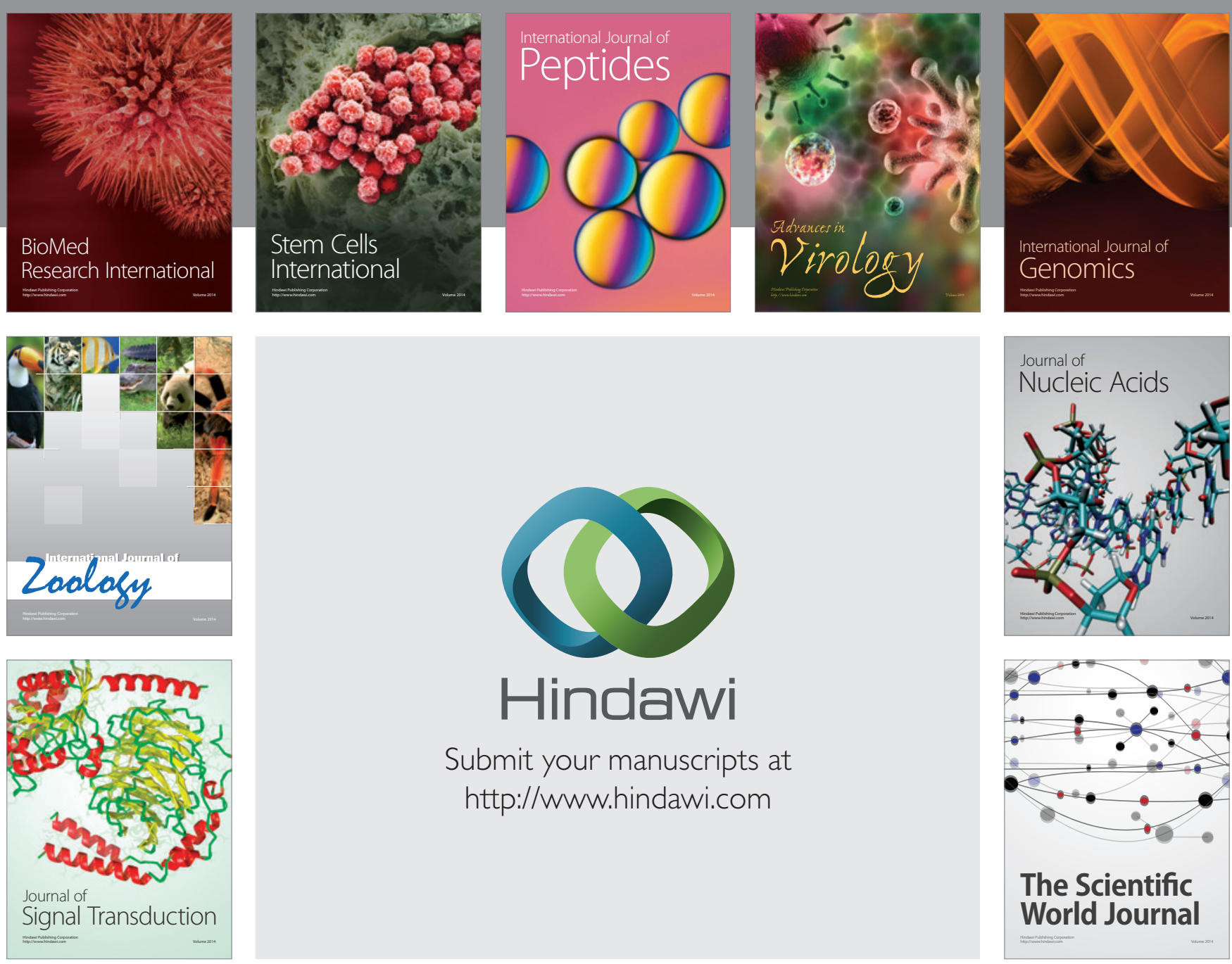

Submit your manuscripts at

http://www.hindawi.com
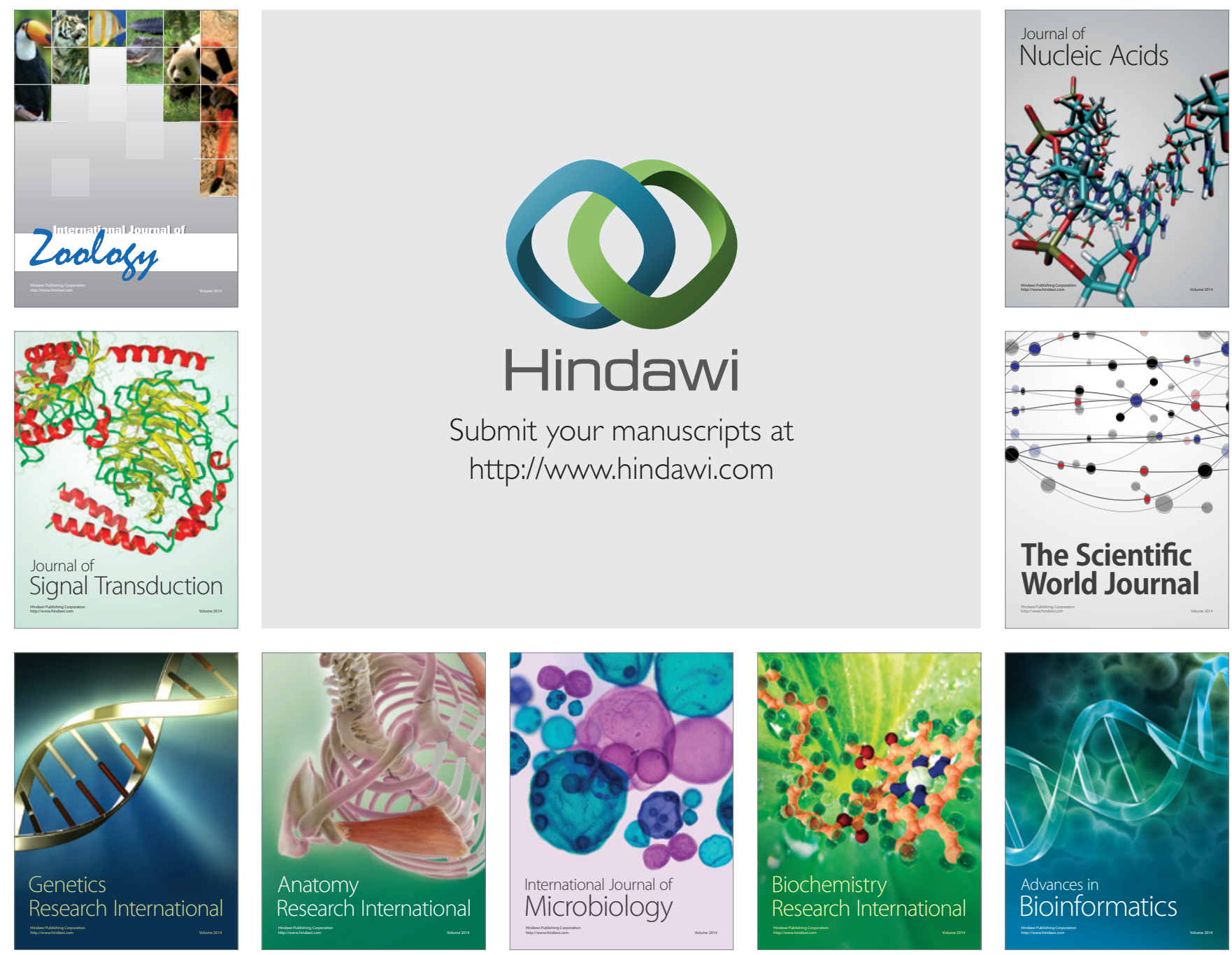

The Scientific World Journal
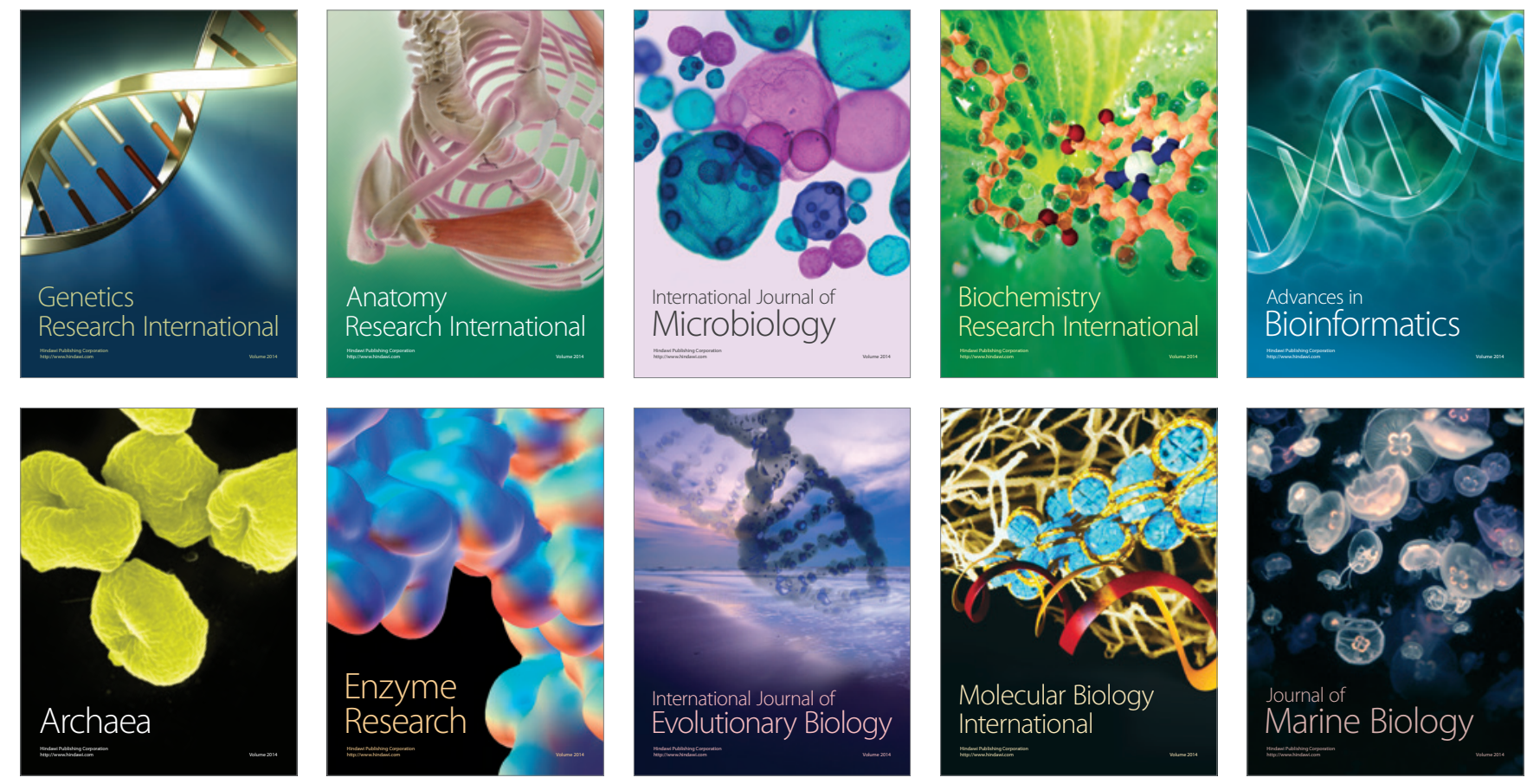